\title{
Assay and Properties of the Enzyme Catalyzing the Biosynthesis of 1-O-Alkyl Dihydroxyacetone 3-Phosphate ${ }^{\dagger}$
}

\author{
PAUL A. DAVIS ${ }^{2}$ AND AMIYA K. HAJRA \\ Department of Biological Chemistry and Mental Health Research Institute, \\ University of Michigan, Ann Arbor, Michigan 48109
}

Received November 12, 1980

\begin{abstract}
The properties of the enzyme alkyl dihydroxyacetone phosphate synthase (1- 0 -acyl dihydroxyacetone 3-phosphate $+\mathrm{ROH} \rightarrow 1-O$-alkyl dihydroxyacetone 3-phosphate + fatty acid) in Ehrlich ascites tumor cell microsomes were studied utilizing a new assay procedure. The assay is based on the difference of partition coefficient between alkyl dihydroxyacetone-P and hexadecanol in an alkaline two-phase $\mathrm{CHCl}_{3}$-methanol-water system. The product of the enzymatic reaction was characterized by different methods as alkyl dihydroxyacetone- $P$. At optimum concentration of the substrates (acyl dihydroxyacetone- $P$ and hexadecanol), detergents or $\mathrm{Mg}^{2+}$ and ATP do not stimulate the reaction. The kinetic properties of the reaction were found to be complex due to the stimulation of enzyme activity at low acyl dihydroxyacetone- $P$ concentration but inhibition at the high concentration of the same substrate. The enzyme accepts a variety of long-chain primary alcohols as substrate without much specificity. With different acyl dihydroxyacetone- $P$, the highest activity was obtained with hexadecanoyl (16:0) dihydroxyacetone$P$, with somewhat less activity with longer octadecanoyl $(18: 0)$ and much less $(40 \%$ of 16:0) activity with tetradecanoyl (14:0) dihydroxyacetone- $P$. Preliminary studies indicate that a Schiff's base intermediate of the enzyme with the keto substrate is probably not formed, since $\mathrm{NaBH}_{4}$ inhibited the enzyme to the same extent in the presence or absence of acyl dihydroxyacetone- $P$. Fatty acids inhibit the reaction and an exchange of fatty acid with acyl dihydroxyacetonc- $P$ in the presence of the enzyme preparation was observed. Heat-inactivation studies indicate that alkyl dihydroxyacetone- $P$ synthase is probably also catalyzing this fatty acid exchange reaction. Based on these findings, an enzyme-bound dihydroxyacetone- $P$ intermediate is proposed.
\end{abstract}

The reaction of fatty alcohol with acyl dihydroxyacetone phosphate (acyl DHAP ${ }^{3}$ ) catalyzed by alkyl DHAP synthase has been shown to be the biosynthetic route to the ether lipids in higher organisms (14). The reaction involves the displacement ${ }^{4}$

\footnotetext{
${ }^{1}$ This work is supported by the National Institute of Health, Grant NS 08841 and Predoctoral Training Grant GM 00187 (to P.A.D.).

${ }^{2}$ Present address: Donner Laboratories, University of California, Berkeley, Calif. 94720.

${ }^{3}$ Abbreviations used: DHAP, dihydroxyacetone phosphate; tlc, thin-layer chromatography.

${ }^{1}$ There are very few known exmples of this type of biochemical reaction. From the nature of the reaction the enzyme may be classified as carbon-oxygen lyase analogous to the thio-ether forming reactions,
}

of the fatty acyl group of acyl DHAP by fatty alcohol to form 1-O-alkyl DHAP. Alkyl DHAP is next reduced by a NADPHdependent reductase to form $1-O$-alkyl-snglycerol-3- $P(7,8)$. This analog of lysophosphatidic acid is then acylated to form the ether analog of phosphatidic acid (9)

e.g., cysteine synthase (EC 4.2.99.8), cystasthionine synthase (EC 4.2.99.9), and $O$-acetyl-L-homoserine acetate lyase (adding methanethiol) (EC 4.2.99.10) where an $O$-ester bond is substituted (by thiol or alcohol) to form a (thio)ether bond. The only other example of such an $O$-ether forming reaction is that described by Murooka et al. (5).

${ }^{5}$ As discussed in Ref. (6), commensurate with the $s n$ nomenclature of glycerolipids, the nonphosphorylated carbon of DHAP is desginated as C-1. 
which is further metabolized, presumably by the same enzyme systems that metabolize phosphatidic acid, to other glycerol ether lipids and also to plasmalogens (10-12).

The activity of the alkyl DHAP synthase in different systems is very low; and the study of the enzyme has been difficult due to the lengthy multistep assay procedures employed $(13,14)$. The present report details a new, simpler assay technique and some properties of alkyl DHAP synthase which were studied by utilizing the new assay technique.

\section{MATERIALS AND METHODS}

Carrier free ${ }^{32} P_{\mathrm{i}}\left(\right.$ as $\left.\mathrm{H}_{3} \mathrm{PO}_{4}\right)$ and $\left[1{ }^{14} \mathrm{C}\right]$ palmitic acid (40-60 $\mathrm{mC}_{\mathrm{i}} / \mathrm{mmol}$ ) were obtained from New England Nuclear (Boston, Mass.). Palmitic acid, ethyl glycolate, and hexadecyl iodide were purchased from Aldrich Chemical Company (Milwaukee, Wis.). Silica gel tlc plates were obtained from Merck (Brinkmann Instruments, Des Plaines, Ill.). Mice bearing Ehrlich ascites tumor cells were a kind gift from Dr. H. N. Christensen.

Radioactive hexadecanol was produced by the reduction of the methyl ester of $\left[1-{ }^{14} \mathrm{C}\right]$ palmitic acid by Vitride [sodium bis(2-methoxyethoxy)aluminum hydride] (1). The methyl ester was prepared by the reaction of palmitic acid $(0.5 \mathrm{mCi} / 10 \mu \mathrm{mol})$ with $2,2-$ dimethoxypropane $(2.5 \mathrm{ml})$ and methanol $(0.4 \mathrm{ml})$ in the presence of IICl $(75 \mu \mathrm{mol})(15)$. The reaction was allowed to proceed at room temperature for $1.5 \mathrm{~h}$ and the excess dimethoxypropane and methanol were removed by evaporation under a stream of nitrogen. The residue was then dissolved in $2.5 \mathrm{ml}$ diethyl ether:benzene solution (4:1) and $0.5 \mathrm{ml}$ Vitride $(70 \%$ in benzene) was added. The tube was tightly capped and incubated for $1 \mathrm{~h}$ at $37^{\circ} \mathrm{C}$. The excess Vitride was destroyed by addition of $10 \mathrm{ml} 20 \%$ ethanol and the radioactive alcohol was extracted by adding $5 \mathrm{ml}$ diethyl ether. After mixing and transfer of the upper layer, the lower layer was extracted twice more with $5 \mathrm{ml}$ diethyl ether. The extracts were then combined, washed with water, and dried by addition of anhydrous $\mathrm{Na}_{2} \mathrm{SO}_{4}$. The ether was removed by blowing a stream of nitrogen. The yield $(99 \%)$ and purity $(>98 \%)$ of the hexadecanol was assessed by thinlayer chromatography in ether:hexane (2:8) on silica gel plates. The radioactive spots were localized by autoradiography, scraped out, and the radioactivity present was determined (7). The $\left[1{ }^{14} \mathrm{C}\right]$ hexadecanol was stored in toluene under $\mathrm{N}_{2}$ at $20^{\circ} \mathrm{C}$. Some polar impurities, formed on prolonged storage ( $>2$ months) were periodically removed by extracting the toluene solution with $0.1 \mathrm{~N} \mathrm{NaOH}$.
Different acyl DHAPs were synthesized by decomposing the corresponding acyl diazoacetone with $\mathrm{H}_{3} \mathrm{PO}_{4}$, and purified by silicic acid chromatography, as detailed by Hajra and Agranoff (16). Acyl [22 P]DHAP was synthesized by decomposing palmitoyl diazoacetone with labeled phosphoric acid (9). These compounds were stored in chloroform:methanol (7:3) at $-20^{\circ} \mathrm{C}$. The acyl DHAP was periodically purified by chromatography on silicic acid as described previously (17).

Microsomes were prepared from Ehrlich ascites cells ${ }^{6}$ essentially by the method of LaBelle and Hajra (7). The microsomal fraction ${ }^{7}$ i.e., the subcellular fraction sedimented between $1.8 \times 10^{5}$ and $3 \times 10^{6} g$ min, was used as the source of the enzyme. The washed microsomal pellet was suspended in $0.25 \mathrm{M}$ sucrose to a concentration of $2 \mathrm{mg} / \mathrm{ml}$. The microsomal preparation was stored frozen in small batches where the enzyme was found to be stable for at least 2 months at $-20^{\circ} \mathrm{C}$. The microsomes were thawed just prior to use and were not reused.

The assay for alkyl DHAP synthase was based on the separation of the radioactive products ([1${ }^{14} \mathrm{C}$ ]hexadecyl DHAP) from the radioactive substrate $\left(\left[1{ }^{14} \mathrm{C}\right]\right.$ hexadecanol) by using a two-phase $\mathrm{CHCl}_{3}-$ methanol-water partition system (22) at high $\mathrm{pH}$ (23). Radioactive hexadecanol (300 nmol, $1.1 \mu \mathrm{Ci})$ and palmitoyl DHAP (90 nmol) were dried down in a test tube under a stream of nitrogen in a heated $\left(40^{\circ} \mathrm{C}\right)$ water bath. The residue was suspended by addition of $\mathrm{NaF}(0.2 \mathrm{ml}$ of $0.1 \mathrm{M})$, water $(0.65 \mathrm{ml})$ Tris-HCl $(0.3 \mathrm{ml}$ of $0.3 \mathrm{M}, \mathrm{pH} 8.5$, total volume $1.15 \mathrm{ml})$, and sonicated for $15 \mathrm{~s}$ in an ultrasonic bath. Enzyme preparation was added $(0.05 \mathrm{ml}, 100 \mu \mathrm{g}$ protein) and the

${ }^{6}$ The activity of alkyl DHAP synthase was found to be high in Ehrlich ascites tumor cells (0.4-0.8 $\mathrm{nmol} / \mathrm{min} / \mathrm{mg}$ of total homogenate protein). In a preliminary survey of normal tissues (18) the activity of this enzyme was found to be highest in developing (14- to 18 -day old) rat brain $(0.6 \mathrm{nmol} / \mathrm{min} / \mathrm{mg}$ protein). Adult rat brain $(0.1 \mathrm{nmol} / \mathrm{min} / \mathrm{mg}$ protein $)$ and liver $(0.06 \mathrm{nmol} / \mathrm{min} / \mathrm{mg}$ protein) have low activity. Among the other tissues, spleen $(0.23 \mathrm{nmol} / \mathrm{min} / \mathrm{mg}$ protein) and testis $(0.19 \mathrm{nmol} / \mathrm{min} / \mathrm{mg}$ protein $)$ also had relatively high activity (18).

${ }^{7}$ The enzyme activity is highest in this "microsomal" fraction. However, the enzyme may be localized in microbodies (microperoxisomes) rather than in the endoplasmic reticulum. In other tissues such as liver and brain, the enzyme distribution profile coincides with that of the peroxisomal marker enzyme, particulate bound catalase (19-20) indicating that the enzyme is probably localized in peroxisomes. However, the absence of peroxisomal marker enzyme catalase in tumor cells $(18,21)$ makes it difficult to establish the exact subcellular localization of alkyl DHAP synthase in Ehrlich ascites tumor cells. 
contents were mixed. The mixture was then incubated for 30 min at $37^{\circ} \mathrm{C}$ in a shaking water bath. The reaction was terminated by adding $4.5 \mathrm{ml}$ of $\mathrm{CHCl}_{3}: \mathrm{CH}_{3} \mathrm{OH}(1: 2)$ and the lipids were extracted by addition of $1.5 \mathrm{ml} \mathrm{CHCl}_{3}$ and $1.5 \mathrm{ml}$ Tris-base $(1.0 \mathrm{M}$, $\mathrm{pH} 10$ ). After mixing well and centrifuging in a swinging bucket rotor $\left(1000 g_{\mathrm{av}} \times 10 \mathrm{~min}\right)$ at room temperature, a $0.5-\mathrm{ml}$ aliquot of upper layer was pipetted into a scintillation vial to which was added a liquid scintillation fluid containing BBS-III (7). The radioactivity present was determined by counting in a Beckman LS-150 or LS-9000 liquid scintillation counter.

The assay based on acyl $\left[{ }^{32} \mathrm{P}\right] \mathrm{DHAP}$ as substrate was performed as detailed by Hajra (13) but with the following modifications. The assay mixture contained substrate amounts equivalent to the ${ }^{14} \mathrm{C}$-based assay (above), and the assay was performed at $\mathrm{pH} 8.5$ except as indicated in the legends to figures and tables. The lipids were extracted under acidic conditions after a $30-\mathrm{min}$ incubation at $37^{\circ} \mathrm{C}$ by addition of 4.5 $\mathrm{ml} \mathrm{CHCl} 3: \mathrm{CH}_{3} \mathrm{OH}(1: 2), 1.5 \mathrm{ml} \mathrm{CHCl}_{3}$, and $1.5 \mathrm{ml} \mathrm{KCl}$ $\mathrm{H}_{3} \mathrm{PO}_{4}(2.0 \mathrm{M}, 0.2 \mathrm{M})$. After mixing and centrifugation, the upper layer was removed and the lower layer was washed with $2 \mathrm{ml}$ of Bligh and Dyer upper layer $\left(\mathrm{CHCl}_{3}: \mathrm{CH}_{3} \mathrm{OH}: \mathrm{H}_{2} \mathrm{O}, 1: 12: 12\right)$ which was acidified by two drops of $6 \mathrm{~N} \mathrm{H}_{3} \mathrm{PO}_{4}$. The lower layer was dried, and the residue was subjected to alkaline methanolysis to remove acyl $\left[{ }^{32} \mathrm{P}\right] \mathrm{DHAP}$, by addition of $2.5 \mathrm{ml}$ $\mathrm{CHCl}_{3}, 0.4 \mathrm{ml} \mathrm{CH}_{3} \mathrm{OH}$, and $0.8 \mathrm{ml} 0.5 \mathrm{~N} \mathrm{NaOH}$ in methanol and incubated for $15 \mathrm{~min}$ at room temperature. One milliliter of $6 \mathrm{~N} \mathrm{H}_{3} \mathrm{PO}_{4}$ was added, mixed well, centrifuged, and the upper layer was removed. The lower layer was washed twice with $2 \mathrm{ml}$ Folch upper layer $\left(\mathrm{CHCl}_{3}: \mathrm{CH}_{3} \mathrm{OH} \mathrm{H} \mathrm{H}_{2} \mathrm{O}, 1: 48: 47\right)$. The $\mathrm{CHCl}_{3}$ soluble radioactivity was determined by liquid scintillation counting ( 7 ).

Hexadecyl DHAP was synthesized as described $(1,21,24)$. The acetonide of chimyl alcohol was prepared by the procedure of Hanahan et al. $(7,25)$. Preparative gas-liquid chromatography was performed using a Varian Aerograph gas chromatograph (Model 920) with a 5-ft $\times 1 / 4$-in. stainless-steel column packed with $1.5 \%$ OV-101 on Chromosorb G at $230^{\circ} \mathrm{C}$. The fractions from gas chromatography were collected in tubes fitted with Millipore filters as described by Hajra and Radin (26).

The other methods employed are as detailed previously $(7,9,18)$.

\section{RESULTS AND DISCUSSION}

\section{Assay}

Two different assays for alkyl DHAP synthase have been described previously $(13,14)$. One is based on the formation of alkali-stable ${ }^{32} \mathrm{P}$-labeled lipid from acyl $\left[{ }^{32} \mathrm{P}\right] \mathrm{DHAP}(13)$ and unlabeled fatty alco- hols. The other (14) is based on the conversion of $\left[{ }^{14} \mathrm{C}\right]$ hexadecanol to $\left[{ }^{14} \mathrm{C}\right]$ chimyl alcohol which is isolated by thin-layer chromatography of the total lipid extract after hydrogenolysis by $\mathrm{LiAlH}_{4}$. The ${ }^{32} \mathrm{P}$ based assay worked well but the procedure was lengthy and a number of manipulations were involved. The second assay method using $\left[{ }^{14} \mathrm{C}\right]$ hexadecanol worked only when there was active phosphomonoesterase present in the incubation mixture to convert the product alkyl DHAP to $\left[{ }^{14} \mathrm{C}\right]$ alkyl DHA since the neutral Bligh and Dyer extraction method used did not extract alkyl DHAP (23). In addition, $\mathrm{LiAlH}_{4}$ or vitride did not quantitatively convert alkyl DHAP to chimyl alcohol (27). This assay method was later modified by employing an acidic extraction method (28).

The present more rapid assay method utilizes the difference between the partition coefficient of the ionic polar product alkyl DHAP and that of the nonpolar substrate hexadecanol in a $\mathrm{CHCl}_{3}$-methanolwater system at high $\mathrm{pH}$. As described previously (23), at high $\mathrm{pH}(>9)$ most $(>95 \%)$ of the acyl DHAP and alkyl DHAP are partitioned into the upper phase of the Bligh and Dyer system whereas all of the hexadecanol remained in the lower layer (18). This assay gave results similar to those obtained with the previous ${ }^{32} \mathrm{P}$-based assay (Table I). The radioactive compound present in the upper layer was identified as $1-\left[1^{\prime}-{ }^{14} \mathrm{C}\right]$ hexadecyl DHAP (see below). When both $\left[1-{ }^{14} \mathrm{C}\right]$ hexadecanol and palmitoyl $\left[{ }^{32} \mathrm{P}\right] \mathrm{DHAP}$ were used in the incubation mixture and $\left[1^{\prime}-{ }^{14} \mathrm{C}\right]$ hexadecyl $\left[{ }^{32} \mathrm{P}\right] \mathrm{DHAP}$ was isolated after alkaline methanolysis and thin-layer chromatography, the ratio of ${ }^{14} \mathrm{C} .{ }^{32} \mathrm{P}$ was $1.05 \pm 0.09$ $(n=4)$. Using the present assay method, the enzyme activity was found to be linear for up to $40 \mathrm{~min}$ and also linear with increasing protein concentration up to 250 $\mu \mathrm{g}$ (Figs. $1 \mathrm{~A}$ and $\mathrm{B}$ ).

Recently, Brown and Snyder (29) described another assay method which separates $\left[{ }^{14} \mathrm{C}\right]$ hexadecyl DHAP from $\left[{ }^{14} \mathrm{C}\right]$ hexadecanol by using anion-exchange (DEAE paper) paper disks. The basic principle of this assay is similar to that described here. 
TABLE I

Comparison of assay Procedures

\begin{tabular}{|c|c|c|}
\hline & \multicolumn{2}{|c|}{$\begin{array}{l}\text { Hexadecyl DHAP } \\
\text { formed (nmol) }\end{array}$} \\
\hline & $\begin{array}{c}\text { Assay A } \\
{\left[{ }^{32} \mathbf{P}\right]}\end{array}$ & $\begin{array}{c}\text { Assay B } \\
{\left[{ }^{14} \mathrm{C}\right]}\end{array}$ \\
\hline Whole system & 2.30 & 2.49 \\
\hline$-\mathrm{NaF}$ & 1.51 & 1.60 \\
\hline -Hexadecanol & 0.14 & - \\
\hline -Palmitoyl DHAP & - & 0.05 \\
\hline $\begin{array}{l}\text { Whole system (no } \\
\text { enzyme control) }\end{array}$ & 0.03 & 0.01 \\
\hline $\begin{array}{l}\text { Whole system (zero } \\
\text { time control) }\end{array}$ & 0.05 & 0.01 \\
\hline
\end{tabular}

Note. Both the assay mixtures contained Tris-HCl buffer (75 mM, pH 8.5), NaF (16.7 mM), hexadecanol (300 nmol; $2.4 \times 10^{6} \mathrm{cpm}\left[1{ }^{14} \mathrm{C}\right]$ hexadecanol in assay B), palmitoyl DHAP (108 nmol; $4 \times 10^{6} \mathrm{cpm}$ palmitoyl $\left[{ }^{32} \mathrm{P}\right]$ DHAP in assay A), and Ehrlich ascites cell microsomes $(0.1 \mathrm{mg}$ protein) in a total volume of $1.2 \mathrm{ml}$. The mixtures were incubated for $30 \mathrm{~min}$ at $37^{\circ} \mathrm{C}$ and the reactions were stopped by addition of $4.5 \mathrm{ml} \mathrm{chlo-}$ roform:methanol (1:2). An acidic extraction and washing method followed by alkaline methanolysis (see text) were used for the assay mixture $A$, and the amount of alkali-stable ${ }^{32} \mathrm{P}$ lipid formed was determined. For assay $B$, an alkaline partition method was used to separate $\left[1-{ }^{14} \mathrm{C}\right]$ alkyl DHAP from $\left[{ }^{14} \mathrm{C}\right]-$ hexadecanol as described in the text and the radioactivity present in the upper layer was determined (see text for more details).

${ }^{a}$ Instead of enzyme, water was added.

${ }^{b}$ The reaction was stopped immediately after enzyme was added by adding $4.5 \mathrm{ml} \mathrm{CHCl}_{3}$ :methanol (1:2).

\section{Identification of the Product}

The radioactivity present in the upper layer of the ${ }^{14} \mathrm{C}$ assay was extracted into $\mathrm{CHCl}_{3}$ after acidification with $1 \mathrm{~N} \mathrm{HCl}$ and the resulting radioactive compound was found to have the same migration rate as authentic 1- $O$-hexadecyl DHAP in two different solvent systems: (I) $\mathrm{CHCl}_{3}$ :methanol:acetic acid:water (25:10:3:1); and (II) $\mathrm{CHCl}_{3}$ :methanol:acetone:acetic acid:water (10:3:4:2:1) (16). The radioactive product was retarded, as was authentic hexadecyl
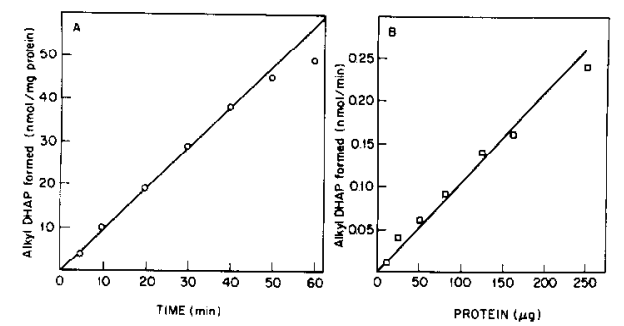

FIG. 1. Effect of increasing time (A) and increasing protein $(B)$ on the biosynthesis of $\left[1^{\prime}-{ }^{14} \mathrm{C}\right]$ hexadecyl DHAP from $\left[1{ }^{14} \mathrm{C}\right]$ hexadecanol and palmitoyl DHAP. The assay is same as described under Materials and Methods. The amount of microsomes used for the time course (A) was $100 \mu \mathrm{g}$ protein and the time of incubation for (B) was $30 \mathrm{~min}$.

DHAP, in a thin-layer chromatography system when the solvent system contained bisulfite (30), indicating the presence of a carbonyl group. Upon reduction either enzymatically with NADPH (7) or chemically by $\mathrm{NaBH}_{4}(9)$, the radioactive product comigrated with authentic 1-Ohexadecyl-rac-glycerol-3-P in solvent I (see above) and was not retarded in the system containing bisulfite (30). When the reduced product was dephosphorylated enzymatically (6), the neutral radioactive product formed, migrated with chimyl alcohol on thin-layer chromatography (7). This product (chimyl alcohol) was converted to acetonide and the resulting acetonide was mixed with carrier acetonide (isopropylidene derivative) of chimyl alcohol and fractionated by preparative gasliquid chromatography (see Materials and Methods). When the eluates were collected and the radioactivity was determined in each fraction, $96 \%$ of the radioactivity was found in the fraction containing the acetonide of 1-O-hexadecyl glycerol. Finally, upon oxidation by periodate $(31,7)$ of the reduced dephosphorylated product (chimyl alcohol), the radioactivity was found to migrate on thin-layer chromatography with authentic 1-O-alkyl glycolaldehyde (7). The presence of the ether bond in the radioactive chimyl alcohol was also confirmed by degradation with $\mathrm{HI}$ to hexadecyl iodide and glycerol as described previously (6). These results prove that the 
product of the reaction is 1-O-hexadecyl dihydroxyacetone 3-phosphate.

\section{Requirements for the Reaction}

The requirements for optimal activity of alkyl DHAP synthase were investigated utilizing the new assay system. The maximal activity was obtained at $\mathrm{pH} 8.5$ in the presence of $\mathrm{NaF}$ (Fig. 2A). The presence of $\mathrm{NaF}$ proved necessary to inhibit the low level of phosphatase activity present in the crude enzyme preparation (18). In the presence of $\mathrm{NaF}$, both the substrate (acyl DHAP) and the product are found to be protected from dephosphorylation. Increasing $\mathrm{NaF}$ concentrations stimulated the enzyme activity in a linear fashion from $0.6 \mathrm{nmol} / \mathrm{min} / \mathrm{mg}$ protein (no $\mathrm{NaF}$ ) to a maximum of $0.9 \mathrm{nmol} / \mathrm{min} / \mathrm{mg}$ protein in the presence of $>15 \mathrm{mM} \mathrm{NaF}$.

No detergent was necessary to obtain maximal activity and the presence of detergents (Triton X-100) or different buffers (Figs. $2 A$ and $B$ ) did not change the $\mathrm{pH}$ optimum of the reaction to a significant extent (Fig. 2). This differs from the report of Rock et al. (28) who found detergent was necessary for maximal activity and for a distinct $\mathrm{pH}$ optimum. This difference probably results from the higher concentration of acyl DHAP used in the

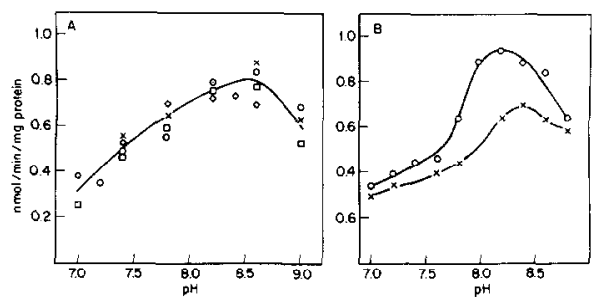

FIG. 2. $\mathrm{pH}$ optimum of alkyl DHAP synthase in different buffer systems and the effect of Triton X100 on the $\mathrm{pH}$ optimum. In (A) the reaction mixture contained buffers ( $50 \mathrm{mM}$, different $\mathrm{pH}$ ), Triton $\mathrm{X}$ $100(0.1 \%),\left[1-{ }^{14} \mathrm{C}\right]$ hexadecanol $(250 \mu \mathrm{M}, 2.1 \mu \mathrm{Ci})$, palmitoyl DHAP $(100 \mu \mathrm{M})$ in a total volume of $1.2 \mathrm{ml}$. Different buffers used were Tris-HCl (O), triethanolamine-HCl $(\diamond)$, EPPS (口), and barbital (x). In (B) the $\mathrm{pH}$ optimum was determined in Tris-HCl buffer (75 mM) with (x) or without $(O)$ Triton X-100 $(0.34 \%)$. The assays were done as described in the text. present assay. Acyl DHAP is a surfactant and therefore at high concentration should disrupt the membrane integrity thus exposing the enzyme fully to the substrates and to the $\mathrm{pH}$ of the incubation mixture.

\section{Effect of $\mathrm{Mg}^{2+}$ Ion and ATP}

It had been described earlier that the reaction is stimulated by ATP and $\mathrm{Mg}^{2+}$ (1). However, ATP was not used as a source of energy (1) and the exact function of ATP and $\mathrm{Mg}^{2+}$ remained unexplained. To resolve this, all the combinations of ATP and $\mathrm{Mg}^{2+}$ were tested for their effect on the activity of alkyl DHAP synthase. As seen in Table II, ATP alone did not stimulate or inhibit the reaction. When magnesium ion alone was added the reaction was inhibited, but there was no inhibition when $\mathrm{Mg}^{2+}$ was added along with ATP. The stimulation of the reaction on ATP and $\mathrm{Mg}^{2+}$ appears to be due to the apparent chelation of the magnesium ion by ATP, thus relieving the inhibition due to the presence of free $\mathrm{Mg}^{2+}$. Other cations $\left(\mathrm{Zn}^{2+}, \mathrm{Ca}^{2+}\right)$ were inhibitory also, presumably by the formation of complexes with the phosphate of the acyl DHAP molecule.

\section{Kinetic Studies}

The new assay method was used to study the kinetics of alkyl DHAP synthesis cat-

TABLE II

THE EFFECT OF $\mathrm{Mg}^{2+}$ AND ATP ON THE $\Lambda$ CTIVITY OF THE ALKYL DHAP SYNTHASE

\begin{tabular}{cc}
\hline \multicolumn{1}{c}{ Additions } & $\begin{array}{c}\text { Activity } \\
\text { (nmol/min/mg protein) }\end{array}$ \\
\hline None & 1.05 \\
$+\mathrm{ATP}(10 \mu \mathrm{mol})$ & 1.06 \\
$+\mathrm{Mg}^{++}(5 \mu \mathrm{mol})$ & 0.23 \\
$+\mathrm{ATP}^{(10 \mu \mathrm{mol})}$ & \\
$+\mathrm{Mg}^{2+}(5 \mu \mathrm{mol})$ & 1.10 \\
\hline
\end{tabular}

Note. The incubation mixture contained palmitoyl DHAP (60 nmol), $\left[1-{ }^{14} \mathrm{C}\right]$ hexadecanol (42 nmol, 2.2 $\mu \mathrm{Ci})$, Tris-HCl (75 mM, pH 7.4), NaF (20 mM), Triton $\mathrm{X}-100(0.05 \%)$, and Ehrlich ascites cell microsomes $(0.1 \mathrm{mg}$ protein) in a total volume of $1.2 \mathrm{ml}$. The mixture was incubated at $37^{\circ} \mathrm{C}$ for $30 \mathrm{~min}$ and the $\left[{ }^{14} \mathrm{C}\right]$ hexadecyl DHAP formed was then extracted and counted as described in the text. 


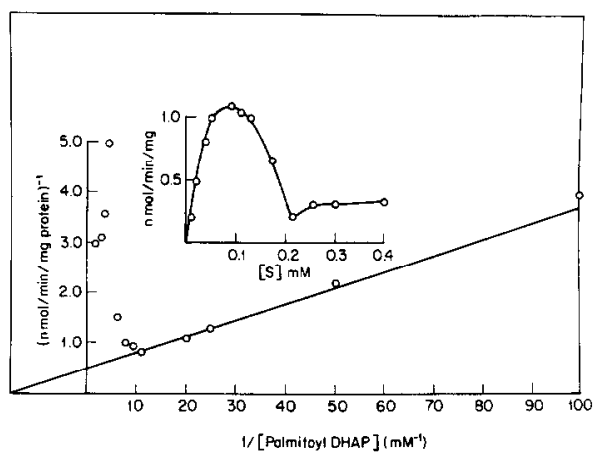

FIG. 3. Effect of increasing amount of palmitoyl DHAP on the activity of alkyl DHAP synthase. The assay was done under standard conditions (see text) with constant amount of $\left[1-{ }^{14} \mathrm{C}\right]$ hexadecanol (300 nmol) and variable amounts of palmitoyl DHAP as indicated. The amount of $\left[1-^{14} \mathrm{C}\right]$ hexadecyl DHAP formed was determined.

alyzed by the enzyme present in Ehrlich ascites cell microsomes with respect to both acyl DHAP (Fig. 3) and fatty alcohol (Fig. 4). As can be seen in Fig. 3, the velocity versus substrate concentration for palmitoyl DHAP displays a maximum followed by inhibition. This behavior is the result of the inhibition of enzyme at high substrate concentration which is probably due to the detergent nature of acyl DHAP. Detergents in general stimulate the reaction at low concentration $(18,28)$, but inhibit the reaction at high concentration (Fig. 2). The substrate versus reaction velocity plot for fatty alcohol (Fig. 4) more closely resembles Michaelis-Menten kinetic behavior. This can be rationalized as being the result of the nonsurfactant nature of fatty alcohol which can be added in high amounts without resulting in inhibition.

The inverse plots for both substrates are also presented in Figs. 3 and 4 . The apparent $K_{m}$ for acyl DHAP was calculated to be $66 \mu \mathrm{M}$ and that for hexadecanol was $45 \mu \mathrm{M}$, while the $V$ values were 2.0 and 1.4 $\mathrm{nmol} / \mathrm{min} / \mathrm{mg}$ protein, respectively. The two $V$ values are different because acyl DHAP inhibits the reaction at high concentration and it was therefore not possible to determine the $V$ for hexadecanol at saturating acyl DHAP concentration.
The numbers derived from these plots suffer from the flaws that affect all enzymes utilizing lipid substrates. The use of the concentration term with respect to lipid substrates is unjustified because lipids are not really soluble but are present in the incubation mixture in both monomeric and micellar forms. Therefore, the exact nature of the substrate as acted upon by the enzyme, along with the concentration of that species is unknown. Other authors have studied this in detail and discussed this problem of kinetic studies for enzymes interacting with lipid substrate $(32,33)$.

The product of the reaction, alkyl DHAP, proved to be inhibitory and the $K_{i}$ for alkyl DHAP was determined using a Dixon plot and found to be $46 \mu \mathrm{M}$. The value obtained again suffers from the same problem as mentioned above but with the assumption that the surfactant activity and physical form of acyl and alkyl DHAP do not differ radically, the enzyme appears to have the same affinity for the substrate as for the product. Fatty acid also proved inhibitory (see later) but the inhibition proved too complex for a simple graphical analysis.

\section{Substrate Specificity}

The specificity of the Ehrlich ascites cell microsomal alkyl DHAP synthase with

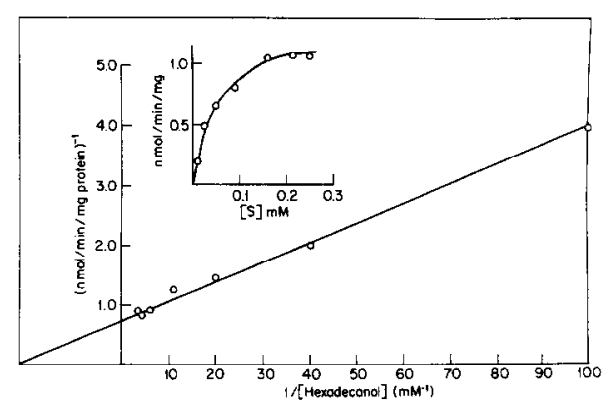

FIG. 4. Effect of increasing amounts of fatty alcohol or the activity of alkyl DHAP synthase. The assay mixture contained Tris- $\mathrm{HCl}(75 \mathrm{mM}, \mathrm{pH} 8.5)$, NaF (20 mM), palmitoyl DHAP (108 nmol), Ehrlich ascites cell microsomes ( $0.1 \mathrm{mg}$ protein), and variable amount of $\left[1{ }^{14} \mathrm{C}\right]$ hexadecanol as indicated. After 30 min at $37^{\circ} \mathrm{C}$ the amount of $\left[1^{\prime}-{ }^{14} \mathrm{C}\right]$ hexadecyl DHAP formed was measured as described in the text. 
respect to alcohol utilized was investigated using the ${ }^{32} \mathrm{P}$-based assay described by Hajra (13). The results are presented in Fig. 5 and are similar to those reported previously from this laboratory $(19,34)$ and also by other workers $(35,36)$. The enzyme utilizes a wide variety of primary alcohols with chain lengths between $\mathrm{C}_{10}$ and $\mathrm{C}_{22}$. The explanation for this nonspecificity may reside in the enzyme requiring only a minimum level of hydrophobicity for activity. However, that hydrophobicity may not be the sole criterion as shown by the decline in activity as the chain length above $C_{18}$. This may be the result of the increasing chain length raising the melting point of the alcohol, thus freezing it out as a solid which is unable to serve as a substrate under the incubation conditions used. This also may explain the high activity found with polyunsaturated alcohols. Alternatively, or perhaps in con-

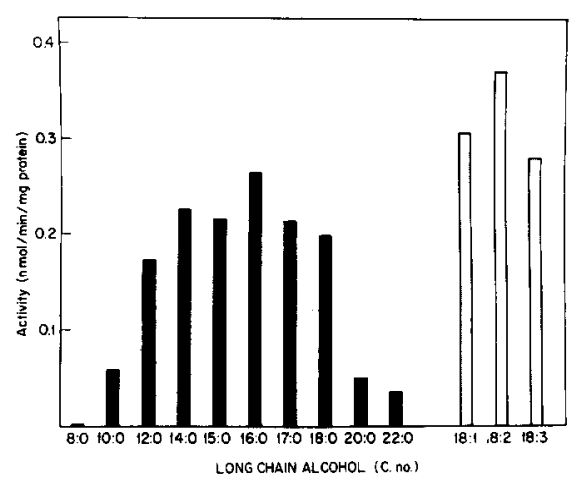

FIG. 5. Activities of various primary alcohols as substrates for alkyl DHAP synthase. The reaction

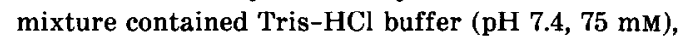
$\mathrm{NaF}$ (16.7 mM), palmitoyl [ $\left.{ }^{32} \mathrm{P}\right] \mathrm{DHAP}$ (16 nmol, 1.2 $\times 10^{5} \mathrm{cpm}$ ), Triton X-100 (50 $\mu \mathrm{g}$ ), Ehrlich ascites cell microsomes $(0.3 \mathrm{mg}$ protein), and various alcohols $(50 \mu \mathrm{g}$ each) in a total volume of $1.2 \mathrm{ml}$. The alcohols used were octanol (8:0), decanol (10:0), dodecanol (12:0), tetradecanol $(14 ; 0)$, pentadecanol $(15: 0)$, hexadecanol (16:0), heptadecanol (17:0), octadecanol (18:0), eicosanol (20:0), docosanol (22:0), cis-9-octadecen-1-ol (18:1), cis-9-cis-12-octadecadien-1-ol (18:2), and cis-9, cis-12, cis-15-octadecatrien-1-ol (18:3). The mixture was incubated for $30 \mathrm{~min}$ at $37^{\circ} \mathrm{C}$, the reaction was stopped by adding $4.5 \mathrm{ml} \mathrm{CHCl}_{3}$ :methanol (1:2), and the lipid was extracted under acidic condition, treated with alkali, and the amount of alkali-stable ${ }^{32} \mathrm{P}$ lipid formed was determined (see text for details). cert with this, the active site of the enzyme may possess only affinity for alcohols with a certain range of chain lengths. This relative nonspecificity means that, as reported, the chain length distribution of the alkyl ether lipids is not controlled by this enzyme but is determined by the specificity of the acyl CoA reductase responsible for the production of fatty alcohols (37).

The specificity of the alkyl DHAP synthase with regard to acyl DHAP species utilized was assessed using the assay method detailed here. The results presented in Table III show that $\mathrm{C}_{18}$ acyl DHAP was nearly as effective a substrate as $\mathrm{C}_{16}$ acyl DHAP while $\mathrm{C}_{14}$ acyl DHAP proved to be less active than either $\mathrm{C}_{18}$ or $\mathrm{C}_{16}$.

\section{Effect of Sodium Borohydride}

Sodium borohydride was used in an attempt to trap any Schiff's base that may be formed between the enzyme and the substrate, containing the ketone group, during the course of the reaction. The experiment involved treatment of the enzyme preparation with borohydride in the presence of the substrate acyl DHAP. The rationale was that, similar to what has been described for aldolase I (38), the enzyme in the presence of acyl DHAP would form a Schiff's base and would be reduced and hence inactivated by the borohydride.

\section{TABLE III}

COMPARISON OF ACTIVITY OF ALKYL DHAP SYNTHASE WITH DIFFERENT ACYL DHAP

\begin{tabular}{cc}
\hline $\begin{array}{c}\text { Chain length of } \\
\text { acyl group in } \\
\text { acyl DHAP }\end{array}$ & $\begin{array}{c}\text { Enzyme activity } \\
\text { (nmol/min/mg protein) }\end{array}$ \\
\hline $14: 0$ & 0.42 \\
$16: 0$ & 1.20 \\
$18: 0$ & 0.95 \\
\hline
\end{tabular}

Note. The incubation mixture contained Tris- $\mathrm{HCl}$ (pH 7.4, $75 \mathrm{mM}), \mathrm{NaF}(20 \mathrm{mM}),\left[1{ }^{14} \mathrm{C}\right]$ hexadecanol (250 $\mu \mathrm{M}, 2 \mu \mathrm{Ci}$ ), and either tetradecanoyl (14:0), or hexadecanoyl (16:0), or octadecanoyl (18:0) DHAP (100 $\mu \mathrm{M}$ ) in a total volume of $1.2 \mathrm{ml}$. The mixture was incubated at $37^{\circ} \mathrm{C}$ for $30 \mathrm{~min}$ and the radioactive alkyl DHAP formed was estimated as described in the text. 
In the absence of acyl DHAP there should be no Schiff's base formed and thus no inhibition due to the reduction of the Schiff's base by borohydride should occur. The various experimental protocols are presented in the legend to Table IV. As can be seen (Table IV), though $\mathrm{NaBH}_{4}$ at higher concentration inhibited the enzyme activity, there was no differential effect of borohydride in the presence and absence of substrate. These results indicate that there is a group or groups on the enzyme that are sensitive to reduction by $\mathrm{NaBH}_{4}$ but a Shiff's base intermediate is probably not formed with the enzyme and acyl DHAP. Friedberg and co-workers have also reported that borohydride treatment in the presence of acyl DHAP does not result in a differential inhibition of the alkyl DHAP synthase and they also concluded that a Schiff's base mechanism is not involved (39).

\section{Exchange Reaction with Free Fatty Acids}

As mentioned above, free fatty acids inhibited the formation of alkyl DHAP from acyl DHAP. We have reported previously that there is a fatty acid exchange activity between the acyl group of acyl DHAP and free fatty acids in the same system where alkyl DHAP is synthesized (40). It was postulated that alkyl DHAP synthase also catalyzed the fatty acid exchange reaction and that a common enzyme-bound DHAP intermediate was formed which may react either with long-chain alcohols to form alkyl DHAP or with fatty acids to form acyl DHAP.

To further establish the identity of the two activities, the heat stabilities of both the alkyl DHAP synthase and the fatty acid exchange activity were determined. The results presented in Fig. 6 indicate that the heat stability of both activities is the same and lends further support to the hypothesis that they are two facets of the same enzyme. Friedberg and co-workers have examined the exchange of $\mathrm{C}-1$ hydrogen with water and have obtained data which they interpret as showing that the release of tritium from labeled acyl DHAP is not dependent on the presence of fatty alcohol (39). These authors postulated the formation of an enzyme-DHAP complex similar to that described by Davis and Hajra (40) (see above).

TABLE IV

The Effect of Sodium Borohydride in the Presence and Absence of Substrate on the ACTIVITY OF ALKYL DHAP SYNTHASE

\begin{tabular}{|c|c|c|c|}
\hline \multirow[b]{3}{*}{ Additions } & \multicolumn{3}{|c|}{ Percentage activity ${ }^{a}$} \\
\hline & \multirow[b]{2}{*}{$\begin{array}{l}\text { Control (no } \\
\text { borohydride added) }\end{array}$} & \multicolumn{2}{|c|}{ Experimental } \\
\hline & & $\begin{array}{l}\text { Borohydride added }{ }^{b} \\
\qquad(2 \mu \mathrm{mol})\end{array}$ & $\begin{array}{c}\text { Borohydride added }{ }^{b} \\
(20 \mu \mathrm{mol})\end{array}$ \\
\hline None & 95 & 89 & 37 \\
\hline Acyl DHAP (90 nmol) & 75 & 87 & 47 \\
\hline Triton X-100 (0.1\%) & 90 & 90 & 31 \\
\hline \multicolumn{4}{|l|}{ Acyl DHAP (90 nmol) } \\
\hline+ Triton X-100 (0.1\%) & 75 & 78 & 38 \\
\hline
\end{tabular}

Note. Ehrlich ascites cell microsomes $(1.0 \mathrm{mg}$ protein) were incubated with or without the presence of 90 nmol of acyl DHAP ( \pm Triton X-100 0.1\%) in $1.0 \mathrm{ml}$ Tris-HCl $(0.15 \mathrm{M}, \mathrm{pH} 7.4)$ for 35 min at $37^{\circ} \mathrm{C}$. Sodium borohydride was added to the experimental tubes $5 \mathrm{~min}$ after the start of the incubation. At the end of incubation, the reaction mixture was diluted with $6 \mathrm{ml}$ sucrose $(0.25 \mathrm{M})$ and centrifuged at $100,000 \mathrm{~g}$ for 30 min. The pellet was resuspended in $0.5 \mathrm{ml}$ sucrose $(0.25 \mathrm{M})$ and the alkyl DHAP synthase activity determined.

${ }^{a}$ Compared to untreated enzme.

${ }^{b}$ Added 5 min after the start of incubation. 


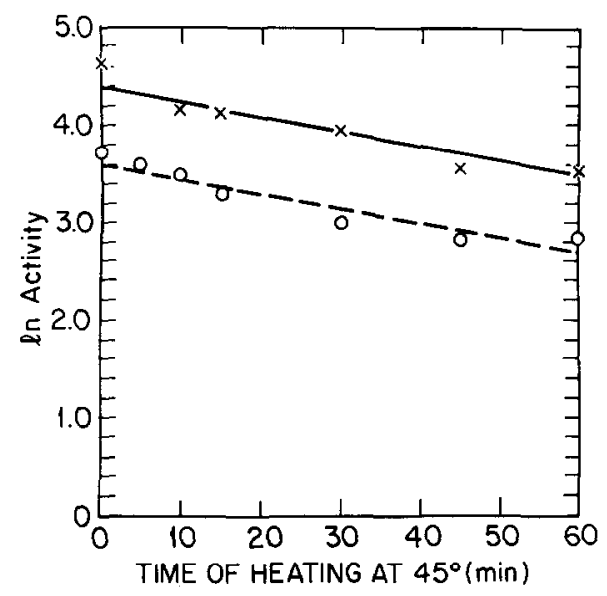

FIG. 6. The stability of alkyl DHAP synthase and the fatty acid acyl DHAP exchange activity in Ehrlich ascites cell microsomes. Ehrlich ascites cell microsomes (12 mg protein) were incubated in $6 \mathrm{ml} 0.25$ $\mathrm{M}$ sucrose at $45^{\circ} \mathrm{C}$. At various times a $0.5-\mathrm{ml}$ aliquot was withdrawn and immediately cooled in ice. The activity of the alkyl DHAP synthase was assessed as detailed under Materials and Methods and the fatty acid exchange enzyme activity was determined as described previously (Ref. (40)). (X) natural log of $100 \times$ alkyl DHAP synthase activity; (O) natural log of $1000 \times$ fatty acid exchange enzyme activity, both in $\mathrm{nmol} / \mathrm{min} / \mathrm{mg}$ protein, at various times of incubation at $45^{\circ} \mathrm{C}$. The data from each activity were fitted to a linear equation using a least-squares linear regression. The line for the alkyl DHAP synthase gave a slope of -0.0147 with a correlation coefficient of 0.94 . The line for the fatty acid exchange activity gave a slope of -0.0153 with a correlation coefficient of 0.87 .

Fatty acid is probably a product of the alkyl DHAP synthase reaction. Free fatty acid is formed when $\left[1-{ }^{14} \mathrm{C}\right]$ palmitoyl DHAP is incubated with the enzyme either alone or with hexadecanol. There seemed to be more fatty acid formed when hexadecanol was present. However, due to the relatively high rate of hydolysis of acyl DHAP in the crude enzyme preparation, the stoichiometry of fatty acid released to the alkyl DHAP formed could not be accurately determined (18).

Attempts to detect the exchange of fatty acids with alkyl DHAP to form acyl DHAP, i.e., the reverse reaction, were unsuccessful. Neither $\left[{ }^{14} \mathrm{C}\right]$ acyl DHAP was detected when $\left[1-{ }^{14} \mathrm{C}\right]$ palmitic acid was incubated with 1-O-hexadecyl DHAP and the enzyme preparation, nor was any alkali un- stable ${ }^{32} \mathrm{P}$ lipid formed enzymatically by incubating palmitic acid with hexadecyl $\left[{ }^{32} \mathrm{P}\right] \mathrm{DHAP}$. These results indicate that the reaction leading to formation of ether bond is probably irreversible.

\section{CONCLUSIONS}

Alkyl DHAP synthase catalyzes a novel reaction in which an activated ester group is substituted by a long-chain alcohol to form an ether bond. The mechanism of the reaction is not obvious but it is known that: (a) a stereospecific exchange of hydrogen from C-1 of acyl DHAP with water occurs with the retention of configuration $(6,39)$; (b) the oxygen from the long-chain alcohol is retained (42); and (c) as discussed above, an enzyme-DHAP complex is probably formed which is not a Schiff's base intermediate. Based on these findings, it may be postulated that an electrophilic enol ester ( 1,2 cyclic ?) may be the intermediate which is attacked by the nucleophilic alcoholate ion (18). The elucidation of the exact reaction mechanism may await the purification of the enzyme so that other enzymatic side reactions are eliminated. However, initial attempts to solubilize the bound enzyme from the crude membrane preparation by different detergents have not been successful. Most of the enzyme activity ( $>90 \%$ ) remains membrane bound on treatment with detergents and very little activity is solubilized. Recently Brown and Snyder (42) have reported the solubilization of alkyl DHAP synthase present in Ehrlich ascites cell microsomes. However, the final specific activity after purification (1.6-fold) as described by these authors is about onetenth of that described in this report, and one-eighth of that described previously from the same laboratory (28). Attempts at present are being made in this laboratory to solubilize and purify this enzyme and then to study its properties in detail.

\section{REFERENCES}

1. Hajra, A. K. (1970) Biochem. Biophys. Res. Commun. 33, 924-935.

2. Wykle, R. L., Piantadosi, C., and Snyder, F. (1972) J. Biol. Chem. 247, 2944-2948. 
3. Friedberg, S. J., AND HeIfetZ, A. (1975) Biochemistry 14, 570-574.

4. Natarajan, V., and Schmid, H. H. 0. (1977) Biochem. Biophys. Res. Commun. 79, 411-416.

5. Murooka, Y., Seto, K., and HaRada, T. (1970) Biochem. Biophys. Res. Commun. 41, 407-414.

6. Davis, P. A., AND HaJRA, A. K. (1979) J. Biol. Chem. 254, 4760-4763.

7. LaBelle, E. F., JR., and HajRa, A. K. (1972) $J$. Biol. Chem. 247, 5825-5834.

8. Chae, K., Piantadosi, C., and Snyder, F. (1973) J. Biol. Chem. 248, 6718-6723.

9. Fleming, P. J., AND HaJRA, A. K. (1977) J. Biol. Chem. 252, 1663-1672.

10. WYKLE, R. L., AND SNYDER, F. (1976) in The Enzymes of Biological Membranes (Martonosi, A., ed.), Vol. 2, pp. 87-117, Plenum, New York.

11. Mangold, H. K. (1979) Angew Chem. 18, 493-503.

12. Paltauf, F., and Holasek, A. (1973) J. Biol. Chem. 248, 1609-1615.

13. HAJRA, A. K. (1969) Biochem. Biophys. Res. Commun. 37, 486-492.

14. WYKLE, R. L., AND SNYDER, F. (1970) J. Biol. Chem. 245, 3047-3058.

15. RADIN, N. S., HAJRA, A. K., AND AKaHORI, Y. (1960) J. Lipid Res. 1, 250.

16. HaJRA, A. K., AND AGRANOFF, B. W. (1968) $J$. Biol. Chem. 243, 1617-1622.

17. HAJRA, A. K. (1968) J. Biol. Chem. 243, 3458-3465.

18. DAvis, P. A. (1979) Ph.D. Dissertation, University of Michigan.

19. HaJRa, A. K., JoNes, C. L., AND Davis, P. A. (1978) Advan. Exp. Med. Biol. 101, 369-378.

20. Bishop, J. E., Davis, P. A., AND HajRa, A. K. (1979) Fed. Proc. 38, 515.

21. Masters, C., AND Holmes, R. (1977) Physiol. Rev. 57, 816-882

22. Bligh, E. G., AND Dyer, W. G. (1959) Canad. J. Biochem. Physiol. 37, 911-917.

23. HAJRA, A. K. (1974) Lipids 9, 502-505.

24. Bleasdale, J. E., Davis, C. S., HaJRa, A. K., AND
AgranOFf, B. W. (1978) Anal. Biochem. 87, 1927.

25. Hanahan, D. J., Ekholm, J., AND JaCKSON, C. M. (1963) Biochemistry 2, 630-641.

26. HaJRA, A. K., AND RADIN, N. S. (1962) J. Lipid Res. 3, 131-134.

27. Blank, M. L., Cress, E. A., Piantadosi, C., and SNYDER, F. (1975) Biochim. Biophys. Acta 380, 208-218.

.28. Rock, C. O., FItzgerald, V., aNd SNYder, F. (1977) Arch. Biochem. Biophys. 181, 172-177.

29. Brown, A., AND SNyder, F. (1980) Fed. Proc. 39, 2032.

30. HajRA, A. K. (1969) Biochem. Biophys. Res. Commun. 33, 929-935.

31. BaumanN, W. J., Schmid, H. H. O., and ManGOLD, H. K. (1969) J. Lipid Res. 10, 132-133.

32. GatT, S., AND BaRTFAI, T. (1977) Biochim. Biophys. Acta 488, 1-12.

33. GATT, S., AND BARTFAI, T. (1977) Biochim. Biophys. Acta 488, 13-24.

34. HAJRA, A. K. (1973) in Tumor Lipids: Biochemistry and Metabolism (Wood, R., ed.), pp. 183199, American Oil Chemists Soc., Champaign, Ill.

35. SNyder F., Clark, M., ANd Piantadosi, C. (1973) Biochem. Biophys. Res. Commun. 53, 350-356.

36. Natarajan, V., and Schmid, H. H. O. (1977) Biochem. Biophys. Res. Commun. 79, 411-416.

37. Bishop, J. E., AND HAJRA, A. K. (1978) $J$. Neurochem. 30, 643-647.

38. MoRSE, D. E., AND HORECKER, B. L. (1968) Advan. Enzymol. 31, 125-190.

39. Friedberg, S. J., Gomillion, D. M., and StotTER, P. L. (1980) J. Biol. Chem. 255, 1074-1079.

40. Davis, P. A., AND HaJRA, A. K. (1977) Biochem. Biophys. Res. Commun. 74, 100-105.

41. SNYDER, F., RAINEY, W. J., BlaNK, M. L., AND Christie, W. H. (1970) J. Biol. Chem. 245, 5453-5456.

42. BRown, A. K., AND SNYDER, F. (1979) Biochem. Biophys. Res. Commun. 90, 278-284. 